\title{
Transatlantica
}

Revue d'études américaines. American Studies Journal

\section{On Archival Research: Recovering and Rewriting History. The Case of Sarah Parker Remond}

\section{Sirpa Salenius}

\section{(2) OpenEdition \\ 12 Journals}

\section{Electronic version}

URL: https://journals.openedition.org/transatlantica/16939

DOI: 10.4000/transatlantica.16939

ISSN: 1765-2766

\section{Publisher}

Association française d'Etudes Américaines (AFEA)

\section{Electronic reference}

Sirpa Salenius, "On Archival Research: Recovering and Rewriting History. The Case of Sarah Parker Remond", Transatlantica [Online], 1 | 2021, Online since 09 July 2021, connection on 03 February 2023. URL: http://journals.openedition.org/transatlantica/16939 ; DOI: https://doi.org/10.4000/ transatlantica.16939

This text was automatically generated on 3 February 2023.

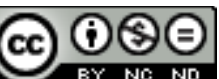

Creative Commons - Attribution-NonCommercial-NoDerivatives 4.0 International - CC BY-NC-ND 4.0 https://creativecommons.org/licenses/by-nc-nd/4.0/ 


\title{
On Archival Research: Recovering and Rewriting History. The Case of Sarah Parker Remond
}

\author{
Sirpa Salenius
}

\section{Acknowledgements:}

I wish to thank Smithsonian American Art Museum and Terra Foundation for supporting my research. I am also grateful to the many archivists who assisted me with locating and consulting the material discussed in this essay. A special mention is due to Professor Laura Giambastiani, Dr. Laura Vannucci, and Dr. Fioranna Salvadori. Thank you.

1 When we think about archives, we often envision them as depositories of official documents, be they diplomatic, political, legal or such private papers as birth certificates or passport applications. Archives, as Caroline Steedman points out, are related to memory, writing, and recording, but also contain "selected and collected rememberings and forgettings" $(5,8)$. These "rememberings and forgettings" belong to personal or collective histories, and consequently contribute to our knowledge of the past, which is constructed through filtering information, a process of selection that is always subjective; it is also based on an interpretation of events, meanings, and documents. History then is created through a repetition of a story, often one representing dominant views that become accepted as the "official" narrative. Repeatedly, this narrative has silenced those whose experiences would contest it. Since certain histories serve specific purposes and because repeated stories, however imagined, have a tendency to gain credibility, such distortions can be seen as dangerous. Many archival documents that are being recovered as well as many stories still interred in the archives are important, in particular when they deal with history that has been suppressed.

2 Overwriting the stories of those pushed to the margins is a manifestation of power, it is a form of divisive separatism, which contributes to the consolidation of power in the hands of those who already possess it. The past of many countries is haunted by the 
presence of anxiety over mastery, over who is entitled to power. In "The White Man's Guilt," originally published in Ebony in 1965, James Baldwin writes:

History, as nearly no one seems to know, is not merely something to be read. And it does not refer merely, or even principally, to the past. On the contrary, the great force of history comes from the fact that we carry it within us, are unconsciously controlled by it in many ways, and history is literally present in all that we do. It could scarcely be otherwise, since it is to history that we owe our frames of reference, our identities, and our aspirations. (42)

The sense of who we are, Baldwin suggests, stems from history that in many ways controls our life trajectories. With the recovery of repressed stories, the familiar history is called into question. Erasure of diversity from dominant narratives reflects the existing power structure: Native Americans, African Americans, immigrants, women, $\mathrm{LGBTQ}+$ community members have all struggled to have their stories written into a more inclusive narrative of the past. The erasure they are subjected to distorts history, leading to the realization that we do not really know our past. Archival work contributes to the changing of the relationship between the dominant mainstream and neglected margin. Moreover, archival work is instrumental in rewriting history that becomes a process of destabilization.

\section{Archival Research: A Pedagogical Tool}

3 Researchers engaged in archival work are commonly driven by curiosity, moving forward in tiny steps, first by discovering various archives and the collections hosted in them, then consulting, transcribing, and perhaps even translating documents before becoming immersed in a meaning-making process. Analyzing, interpreting, and selecting information that is useful precede the presentation or publication of the results. As scholars have pointed out, archival work can be tedious and timeconsuming, and archival researchers usually have no formal training for the work they do but they have to learn on their own "how to search for documents, how to talk to archivists," how to treat the documents and findings, and how to subtract relevant information from them; they often have to learn through trial and error how to take notes and interpret their findings (Ramsey et al. 1,3). Fortunately, the situation is gradually changing as conferences, workshops, and symposiums are being organized to discuss student involvement in archival work and the use of archives in research and teaching in general. ${ }^{1}$ Another welcome sign is that universities are starting to offer rhetoric, composition and literature courses in which archival recovery work is an integral component. Wendy Hayden offers several examples of such courses, pointing out the positive outcomes: students "produced work that show enhanced skills of close reading and analysis and illustrate how a major benefit to assigning this type of research to undergraduate students is its invitation to students to produce more meaningful scholarship that makes a contribution to an academic field of study" (135). Other benefits include an increase in student engagement as they "become invested in helping to recover local histories" (Hayden 137). Work based on archival research, as Hayden notes, becomes a process of "knowledge production" rather than being only a form of "knowledge accumulation" (145). For the most part, though, these archives university students access tend to be digital, available in already existing databases. It is one thing to deal with metadata, another to work in physical archives. In both 
scenarios, though, collaborative exchange between institutions, archivists, and researchers is encouraged, as also Tarez Samra Graban, among others, suggests (188).

Archives can be interpreted broadly, as Lynée Lewis Gaillet does, to include

a wide range of artifacts and documents, such as (unpublished and published)

letters, diaries and journals, student notes, committee reports, documents and wills, newspaper articles, university calendars / handbooks / catalogs, various editions of manuscripts and print documents (books, pamphlets, essays, etc.), memos, course materials, online sources, audiotapes, videotapes, and even 'archeological' fragments and finds. (30)

The vast variety of material may also include court records, school records, death certificates, and so on. In my own work, archival documents have ranged from private correspondence and journals to newspaper reports, passport applications, and to college and medical school records.

\section{A Case Study: Sarah Parker Remond}

Image 0. "Sarah P. Remond," photograph by unknown photographer, no date, Portraits of American Abolitionists, photograph number 81.448, Massachusetts Historical Society. Courtesy of the Massachusetts Historical Society.

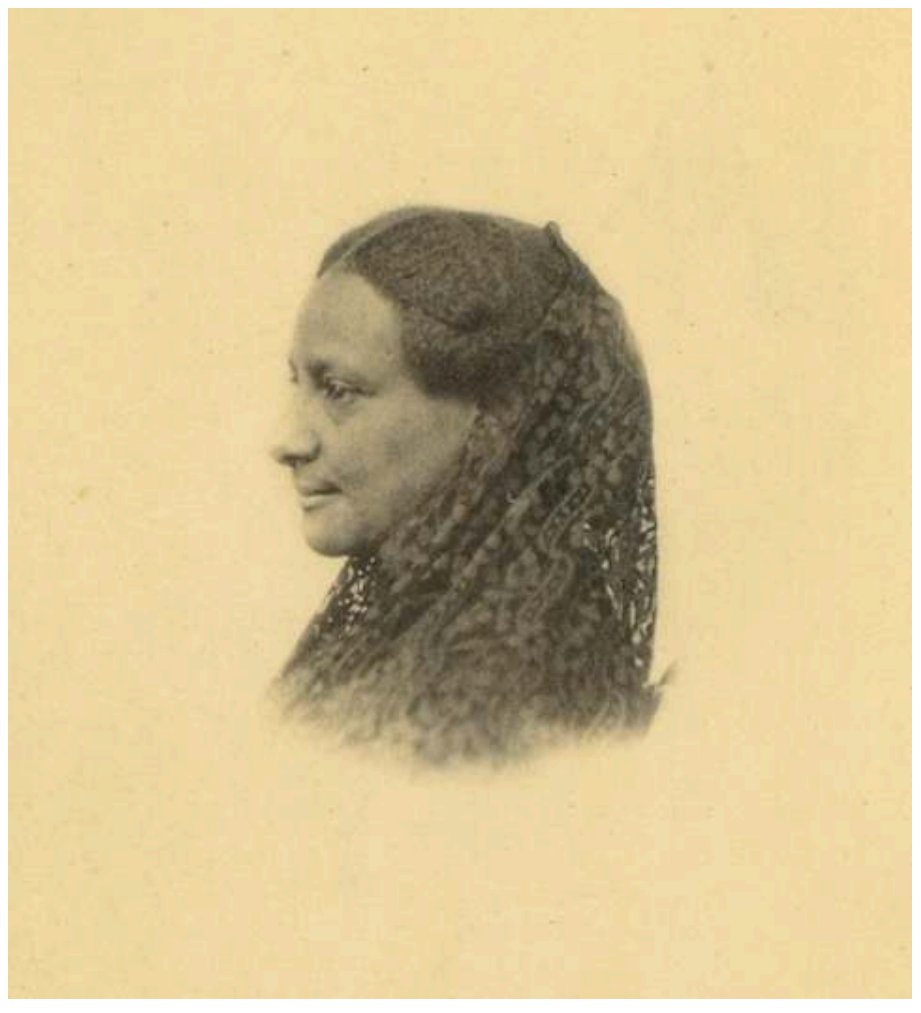

5 The archival work I have immersed in has focused on recovering nineteenth-century women's experiences and accomplishments, for instance those related to the author, historian, and First Lady, Rose Elizabeth Cleveland (1846-1918), who lived in a samegender relationship with Evangeline Whipple (1857-1930) during the last years of her life in Italy. I have also examined nineteenth-century African American travelers in Europe, mainly Sarah Parker Remond, her sister Caroline Remond Putnam, and nephew, Edmund Putnam. These figures are prominent models for alternative black and non-normative experiences, promoting acceptance of non-heterosexuality and 
equality between white and black. The aim of my research has been to foster engagement in alternative realities by sharing stories recovered from various archival sources but also to generate awareness of the ways in which images and impressions of the marginalized, many of them women, may remain overshadowed by mainstream narratives.

Researchers working in various archives tend to agree that it would be profitable for future projects that archival documents, often stored in places that are hard to access, were shared among scholars, to render them accessible also to others who wish to continue the work on recovering the voices of those who have been silenced, rewriting their inspirational stories back into the history that erased them. Although digital archives and open access have decentralized archives and decolonized knowledge production, online sources are not always an immediate option for sharing archival findings. Problems may arise particularly due to ownership and copyright issues. Moreover, as more information becomes accessible online, documents and interpretations may lead to the creation of contradictory and confusing narratives. For instance, there are three different dates circulating about the birth year of Sarah Parker Remond (1826-1894), the case study of this essay. Some claim that she was born in 1815, others suggest in 1824 or 1826. A Salem, Massachusetts census from August 1850 lists Sarah Parker Remond as being 26 years old at the time, which would mean that she was born in 1824, whereas another Salem, Massachusetts census from August 1855 indicates that Sarah P. Remond was 29, which would place her year of birth in $1826 .{ }^{2}$ The nineteenth-century censuses, as is evident, were not always accurate. The information contained in Remond's British passport application would confirm 1824 as her year of birth as it states that she was 41 years old when the document was signed in $1865,{ }^{3}$ but her U.S. passport application, dated 8 September 1858 , is the only document I know of that actually states that she was born on 6 June $1826 .{ }^{4}$ This is supported by the information in her passport, which is described in the journals of Benjamin Moron, representative of the U.S. legation in London, who had access to the passport when Remond applied for a visa to France. 1826 is also confirmed by Remond's marriage certificate, dated 25 April 1877, which states that at the time she was fifty (image 1). ${ }^{5}$ It would seem plausible then to conclude that Sarah Parker Remond was born in 1826. But without access to all these different information sources, all of them archival documents scattered all over the world (London, U.K., Salem and Washington DC, U.S.A, and Florence, Italy), it would be nearly impossible to determine the year of her birth.

7 The free-born African American anti-slavery lecturer, Sarah Parker Remond is my case study for exploring the difficulties and rewards of archival research. Remond was not a writer per se, but she wrote pamphlets and gave eloquent antislavery talks. She had a successful transatlantic career promoting race and gender emancipation first in the United States, then touring in England, Scotland, and Ireland before she moved to Florence, Italy to study at one of Europe's most prestigious medical schools, the Santa Maria Nuova, in 1866. Nineteenth-century American newspapers reported of her arrival in "Firenze la Bella" with the intention of studying there but they offer hardly any additional information about her life and studies in Italy.

8 My search for information about her transatlantic experiences was triggered by the desire to learn more about this exceptional woman of whom there seemed to be very little information available. Since I was in Florence, Italy at the time, the first question I wished to answer concerned the medical school records: did they exist, where could 
they be stored, and what might they contain? The obvious place for hoping to locate them would have been the Santa Maria Nuova hospital in Florence, but after contacting various departments there, it became evident that they had no information concerning the location of any possible archives related to students who had attended the medical school in the nineteenth century. After several months of exchanging emails with various archivists, librarians, colleagues, medical school and hospital administrative offices around Italy in search of leads as to where the documents might be located, one archivist suggested I try the University of Florence. The thrill of discovery was intense when I received a reply from one of the archivists working there: the documents were at the University of Florence archives, in binders that were stored in one of the university's conference rooms. Since that space was actively used for meetings, the archivist at the time in charge of the documents had access to the room only a few times a month and only for a few hours at a time. It took some time before we finally were able to meet. The meeting took place at the conference room where the medical school records were deposited. Most probably, the binders had not been opened since the nineteenth century. The difficulties and time invested in locating the archives were rewarded by the excitement of consulting these documents that probably nobody had examined after they were gathered together in the dossiers.

9 I went through several binders, not quite knowing what I was looking for before I saw a list of student names, those who had been accepted at the Department of Obstetrics for the academic year 1866-67. Among them was "Sarah Parker Remond, negra d'America" ("Negro of America"), who was admitted to audit classes (image 2). ${ }^{6}$ The same folder contained a statement confirming that the "Negro" Sarah Parker Remond of America was admitted as auditor at the obstetrics Clinic as she had requested (image 3). ${ }^{7}$ Following was a letter written by Remond herself requesting to be admitted to the medical school (image 4). ${ }^{8}$ The paper she had used for writing the letter had Remond's initials at the top (SR). It evoked a sense of taste, sophistication, education, and class status. In her application, dated Casa Iandelli (a hotel in central Florence), 30 October 1866, Remond explained that she lived in London but was planning to spend the winter in Florence. She requested to be admitted to the Santa Maria Nuova clinic of obstetrics and stated that with her letter, she enclosed testimonials from the University College London Hospital. Their function obviously was to support her application.

The request was, indeed, accompanied by two letters of recommendation and a letter signed by B.B. Appleton, M.D., a member at the Massachusetts Medical Society (image 5). ${ }^{9}$ Dr. Benjamin Barnard Appleton (1815-1879), a relative of Fanny Appleton (1817-1861), the first wife of the American poet Henry Wadsworth Longfellow, was born in Boston on 4 May 1815. He graduated from Harvard Medical school in 1839 (Harvard Medical School 23), was a medical instructor at Harvard in $1845-46$, had a practice in Boston at 29 Boylston Street, and he was involved with both the Boston Dispensary (an early hospital in the city founded in the 1790s) and the Boston Athenaeum. By 1865 he was in Florence, Italy, where he was the secretary at a meeting of American citizens there to discuss the assassination of Abraham Lincoln on 2 May $1865 .{ }^{10}$ According to the letter, dated 30 October 1866, Appleton was residing in Via Mazzetta in Florence, close to where Remond had found accommodation. He assisted American travelers in Florence, among them Julia Ward Howe. In 1869 he was living with an Italian family who formerly had been in the Grand Duke's service (Stearns n.p.). In April 1870, Dr. B.B. Appleton was still living in Florence. He had been the predecessor of Edward Everett Hale, the American Unitarian minister, author and historian, "in keeping the Latin 
school, No. 12 Via dei Caldie [probably Via delle Caldaie], 3rzo Piano [3 $3^{\text {rd }}$ floor] on the Pitti side of the river, at whose house is his sister in law, Miss Matty Brooks" (Hale 112). Appleton, who had enclosed his medical certificates with his letter, was asking to be allowed to partake in the lessons regularly offered at the Santa Maria Nuova hospital's Faculty of medicine and surgery. The certificates were not in the binder, so it is probable that they were returned to him. Since his name does not appear anywhere in the hospital school records, he may have been denied access, was not officially admitted and hence not formally registered, or the documents still need to be located. But when Remond first arrived in Florence, Dr. Appleton, according to American newspapers, accompanied her to call on the Italian nationalist, Giuseppe Garibaldi. Some also claimed that Remond had "studied medicine with Dr. Appleton-the friend and physician of Theodore Parker, during the latter portion of his life at Rome and Florence," while another newspaper stated that she had studied medicine "under Dr. Appleton in Boston." ${ }^{11}$ It is possible, then, that Dr. Appleton attended classes at the Santa Maria Nuova Hospital school together with Remond but the archival documents confirming it still need to be found; they may well be among the documents located at the State Archives in Florence (Archivio di Stato di Firenze). There is no inventory of these papers as of yet.

11 The recommendation letters supporting Remond's application, signed by Sister Rosmonda from the All Saints University College (image 6) $)^{12}$ and M. Berkeley Hill, one of the Head Surgeons at the University College (image 7), ${ }^{13}$ provide information about Remond's previous studies of medicine at University College London in the departments of midwifery and surgery and her graduation as a nurse. Both letters were translations, assumingly from English, copied on a paper of delicate purple hue that carried the same initials, SR, at the top of the sheet. Sister Rosmonda declared with great pleasure, as she wrote, that Remond had obtained her education as a nurse in medicine and surgery at the University College Hospital. In absence of Mother Superior, Sister Rosmonda attested on her behalf to Remond's zeal in her work, to her skills, energy, untiring attention, and kindness toward the patients under her care. The letter was dated 19 June 1866. Dr. Hill's letter, dated 12 June, attests that as one of the head surgeons of the University College he had observed Remond working under the supervision of the Sisters in the various departments of the hospital; it had been his great pleasure to witness the assiduous way in which Remond had always rendered her services in taking care of the patients' needs. Dr. Hill, who had studied in England and the Continent, and at the time practiced in various hospitals, considered himself competent to affirm that the training provided by the All Saints Sisters at the University College Hospital was in every way equal to that offered elsewhere. According to Dr. Hill's testimony, Remond had learnt everything that was necessary for becoming a perfect hospital nurse. He concluded the letter by stating that he considered Remond extremely capable of assuming service at a hospital or in a hospital department. He wished Remond good luck and closed the letter by affirming to be her sincere friend. Both letters came from a prestigious London medical school and both highly praised Remond's work ethic, dedication, and attitude toward patients.

12 In another letter written by Remond herself, dated 13 November 1867, at No 8 Via $S[a n t o]$ Spirito, she declared that "Sara Parker Remond of Boston, United States of America" was desirous to have a career in obstetrics and hence, was requesting to be admitted to take classes. She further explained that the above mentioned S. P. Remond had already studied at the school for a year (image 8). ${ }^{14}$ Another archival document 
contains names of women, among them Remond, who had submitted a request to be admitted to the medical school for the academic year 1867-68 (image 9). ${ }^{15}$ The information given includes the name of the father " GGiovanni," which is a translation of "John"), Remond's age: 42 (which would mean that she was born in 1826 if she had entered her $42^{\text {nd }}$ year in fall 1867), her place of origin ("Boston"), and residence ("Via S[anto]. Spirito 8, Firenze). In these documents Remond's first name was Italianized to 'Sara,' which may indicate an identification with her peers who were all Italian and her assimilation into the local society (image 10). ${ }^{16}$ Some of the students who had taken the entrance examination to be admitted ("ammessa") for the academic year 1867-68, passed the test well, others, like Remond, with top marks ("benissimo") (image 11). ${ }^{17}$ When requesting permission to study at the obstetrics clinic, "Parker Remond Sara" had accentuated her last name, which indicates its pronunciation in Italy, with emphasis on the first syllable of the name, which differs from how it is commonly pronounced in the United States (image 12). ${ }^{18}$ The worksheets (January-July 1868; her name is not included in the April list) show the shifts and teams in which Remond practiced during her studies (image 13).

"Remond Parker Sara" subsequently requested to be allowed to take the final habilitation examination. A statement from the Section of Surgery, dated 22 July 1868 on the subject of Remond Sara, explained that after having participated in classes with rare diligence and completed all required scholarly obligations, Remond had requested permission to take the final examination. In consideration of her exemplary conduct when auditing classes and the practical work she mastered, the report stated, the school was in favor of letting her take the examination, despite the fact that she had attended the school for eight out of the sixteen required months of study. A discussion followed whether she could be allowed to take the habilitation examination, but all reports praised her remarkable skills (image 14). ${ }^{19}$ This testifies to Remond's exceptional talent, skills, and probably hard work. These letters, written in formal nineteenth-century Italian, are challenging to transcribe and translate. But it is clear that in the end, the Santa Maria Nuova Hospital School gave Remond permission to take the habilitation examination (images 15, 16, and 17).20 "Remond, Sarah Parker, daughter of John, native of Salem, United States" took the practical test on Tuesday 4 August 1868 and the habilitation examination on 11 August 1868 (image 18). ${ }^{21}$ It is highly probable that Remond, again, passed the examination with excellent marks.

\section{What to do with archives?}

After having discovered these documents I had to face several challenges. Photocopying and scanning at the time were not options so I had to take notes and (unprofessionally) photograph the documents. Another problem was that they were not indexed anywhere, nor did they have any assigned method for citing them, which made it difficult to relocate them should there be a need to do so. At times, the handwriting of the medical doctors and professors was hard to read, so with limited time in the archives, some important documents may have been overlooked. It is also possible that I have introduced errors in transcribing and translating the documents or interpreting their contents. For instance, it may be plausible to consider that Remond had Dr. Appleton write her letter of application, which she then copied in her own handwriting. In Appleton's handwriting the letters $L$ and $S$ are very similar (see 
"Signore" and "Sezione" at the beginning of the letter; the latter $S$ closely resembles $L$ ); Remond seems to have confused them in her own letter, writing "della Lezione Medica e Chirurgica" and "Lezione Ostetrica" although perhaps it should have been "Sezione" (images 4 and 5). Or perhaps Remond's knowledge of Italian before starting her studies was limited. These are just some possibilities out of many.

The question of interpretation, to some extent, overlaps with the process of selection: determining what information is important to the story one is trying to tell. Archival work requires decisions concerning which documents may be useful and should be accessible to others, and to what extent they should be publicized, where and in what way, and how to remind readers that although they are rendered accessible, there still may be copyright and permission issues to deal with before anyone can post them on their blogs or other websites. The selection process involves ethical questions. ${ }^{22}$ In the case of Rose Elizabeth Cleveland, for example, it is imperative to evaluate, then decide if and to what extent her very private letters of intimate sexual experiences should be rendered public. Would she have wanted that information circulating publicly and can it still have an impact on her relatives? Moreover, the emphasis on her non-normative sexuality may overshadow her literary achievements and work on women's emancipation. In Remond's case the decisions mainly relate to selecting the documents that are most relevant to her experience as a medical student at the Santa Maria Nuova hospital school. The testimonies written by her supervisors and professors both in England and Italy are celebratory. Such praise as she received should surely be rendered public.

The Santa Maria Nuova medical school records form merely one small piece of a larger mosaic testifying to the richness of Remond's life. Other documents are scattered around in various archives in the United States, Great Britain, and elsewhere in Italy. Like all archival recovery work, gathering the pieces that would render the depth of her experiences visible requires time, dedication, and funding. The end result, though, is undoubtedly rewarding.

17 Archival recovery work serves to deconstruct dominant historical narratives, reconstruct memory, and may perhaps even lead to the self-validation of those pushed to the margins. It embraces the richness of previously experienced realities that should be included in collective dominant narratives, thus mediating between margin and mainstream. In many cases, it contributes to a dynamic process of positive selffashioning rendered available to those who finally have access to historical models they can emulate; archival work recovers examples of pioneers whose stories are finally being retold. Archival recovery work, then, contributes to the rewriting of our collective histories.

\section{BIBLIOGRAPHY}

BALDWIN, James. “The White Man's Guilt.” Dark Days. Penguin, 2018. 
GAILLET, Lynée Lewis. "Archival Survival: Navigating Historical Research.” Working in the Archives: Practical Research Methods for Rhetoric and Composition. Eds. Alexis E. Ramsey, Wendy B. Sharer, Barbara L'Eplattenier, and Lisa S. Mastrangelo. Carbondale: Southern Illinois University Press, 2010, p. 28-39.

GRABAN, Tarez Samra. "From Location(s) to Locatability: Mapping Feminist Recovery and Archival Activity through Metadata." College English, vol. 76, no. 2, Special Issue: The Digital Humanities and Historiography in Rhetoric and Composition, 2013, p. 171- 93.

HALE, Edward E. Jr. The Life and Letters of Edward Everett Hale. Vol. 2. Boston: Little, Brown, and Company, 1917.

HARVARD Medical School. Annual Circular of the Massachusetts Medical College: With a History of the Medical Department of Harvard University, A Catalogue of Graduates. Boston: David Clapp, 1846.

HAYDEN, Wendy. “And Gladly Teach: The Archival Turn's Pedagogical Turn.” College English, vol. 80 , no. 2, 2017, p. 133-58.

MCKEE, Heidi A., and James E. PORTER. "The Ethics of Archival Research." College Composition and Communication, vol. 64, no. 1, 2012, p. 59-81.

NATIONAL ARCHIVES, UK. nationalarchives.gov.uk/. Accessed 3 April 2021.

RAMSEY, Alexis E., Wendy B. SHARER, Barbara L'EPLATTENIER, and Lisa S. MASTRANGELO, eds. "Introduction." Working in the Archives: Practical Research Methods for Rhetoric and Composition. Carbondale: Southern Illinois University Press, 2010, p. 1-8.

STEARNS, Frank Preston. Cambridge Sketches. n.p., 1905. gutenberg.org/cache/epub/7255/pg7255images. Accessed 12 January 2021.

STEEDMAN, Caroline. Dust: The Archive and Cultural History. Manchester: Manchester University Press, 2001.

\section{NOTES}

1. Examples are the "Women in the Archives: Using Archival Collections in Research and Teaching on U.S. Women" symposium held in Portland, Maine in June 2009 and "History Lost? Saving Louisiana's Archival Heritage" workshop organized at the University of Louisiana at Lafayette in 2018.

2. These documents can be found on Ancestry.com

3. Accessible through the National Archives, UK, nationalarchives.gov.uk/. According to the naturalization records specialist, the applicant would have supplied their age, which no one would have checked or questioned. Since the document is not in Remond's handwriting and in the winter of 1865 she was traveling, for instance in Bristol, then perhaps her supporters submitted the application on her behalf, then signed it in June 1865 without realizing that they had given wrong information about her age.

4. A copy of Remond's passport, from National Archives and Records Administration (NARA), Washington D.C, downloadable from Ancestry website. Transcription:

United States of America

Commonwealth of Massachusetts

county of Essex On this eight day of September AD eighteen hundred \& fifty eight, before me Joseph W. Waters Notary Public, duly commissioned \& sworn, residing at Salem, in said County, personally appeared Sarah P. Remond of Salem aforesaid singlewoman [sic] well known to me as a citizen of Salem aforesaid, and made oath that she is a native citizen of the United State 
aforesaid, and that the following is a true description of her person. She is aged thirty two years having been born at Salem in Massachusetts on the sixth day of June 1826 is about five $1 / 2$ feet in stature, forehead high eyes black nose straight mouth full chin not prominent hair dark complexion \& thin face.

Sarah P[.] Remond

Also appeared at the same time Samuel P[.] Andrews well known to me as a native citizen of the United States, who being also duly sworn, made oath that he is well acquainted with the above named Sarah P. Remond, and verily believes that she was born in Salem in the County of Essex.

\section{Samuel P. Andrews}

In testimony whereof I hereunto set my hand \& affix my notarial seal, on the day \& year above written

Joseph Waters Notry Public

5. "su concessione dell' Archivio Storico del Comune di Firenze." The marriage took place on 25 April 1877 at 9:15 pm at the City Hall of Florence. According to the marriage certificate, Lazzaro Pintor was 44 years old, office worker, born in Cagliari, resident in Florence, son of Vincenzo, resident in Cagliari, and deceased Clara Piccaluga resident in Cagliari; Sara P. Remond, age 50, housewife, born in Salem (America), resident in Florence, daughter of deceased Giovanni [John italianized], resident in Salem and deceased Nancy Lenox, resident in Salem. The testimonies at the marriage were Mc Giovanni Dougall [John McDougall], age 44, Scottish priest and Eugenio Alessandri, age 29, office worker, both residents in Florence. Transcription:

Atti di matrimonio

Numero 378

Pintor Lazzaro

P. Remond Sara

L'anno milleottocentosettantasette, addì venticinque di Aprile, a ore pomeridiane nove e minuti quindici nella Casa comunale di Firenze, in una sala aperta al pubblico. Avanti di me Cavaliere Marchese Pietro Torrigiani Assessore delegato con Atto del Sindaco dei venticinque Novembre milleottocentosettantatre Uffiziale dello Stato Civile, vestito in forma ufficiale, sono personalmente comparsi: $1^{\circ}$. Lazzaro Pintor, di anni quarantaquattro Impiegato, nato in Cagliari, residente in Firenze, figlio di Vincenzo, residente in vita a Cagliari, e di fu Clara Piccaluga residente in vita a Cagliari; $2^{\circ}$. Sara P. Remond, di anni cinquanta, Attacasa, nata in Salem (America), residente in Firenze, figlia di fu Giovanni, residente in vita a Salem, e di fu Nancy Lenox, residente in vita a Salem, i quali mi hanno richiesto di unirli in matrimonio; a questo effetto mi hanno presentato il documento sotto descritto; e dall'esame di questo, non che di quelli già prodotti all'atto della richiesta delle pubblicazioni, i quali tutti, muniti del mio visto, inserisco nel volume degli allegati a questo registro, risultandomi nulla ostare alla celebrazione del loro matrimonio, ho letto agli sposi gli articoli centotrenta, centotrentuno e centotrentadue del Codice Civile, e quindi ho domandato allo sposo se intende di prendere in moglie la qui presente Sara P. Remond, e a questa se intende di prendere in marito il qui presente Lazzaro Pintor; ed avendomi ciascuno risposto affermativamente a piena intelligenza anche dei testimoni sotto indicati, ho pronunciato in nome della legge che i medesimi sono uniti in matrimonio. A quest'atto sono stati presenti:

Mc Giovanni Dougall di anni quarantaquattro, Pastore scozzese, e Eugenio Alessandri di anni ventinove, Impiegato, entrambi residenti in questo Comune. Il documento presentato è il Certificato dell'Unica [?] pubblicazione eseguita qui nel dì quindici Aprile stante per dispensa ottenuta dal Procuratore del Re a questo Tribunale Civile e Correzionale con ordinanza in data dodici Aprile del corrente mese come dal Registro di pubblicazioni sotto il suo vero numero [?]. Letto il presente atto agli intervenuti si sono essi meco sottoscritti

Lazzaro Pintor

Sarah Remond 
Giovanni R. McDougall

Eugenio Alessandri

Pietro Torrigiani

6. "Remond Sarah, negra d'America ammessa come uditrice" (Cancelleria degli Studi Affari Spediti anno 1866-67, Filza 74, affare 11).

7. The statement is dated 22 December 1866, carries the name of Pietro Vannoni, and states: "La negra Sarah Parker Remond d'America è ammessa a frequentare in qualità di uditrice l'insegnamento di Clinica Ostetrica conforme con la fatta domanda"; below the signature of "Prof Vincenzo Balocchi" (Cancelleria degli Studi Affari Spediti anno 1866-67, Filza 74, affare 11).

8. Remond's letter, dated "Casa Iandelli. Octobre 30. 1866" reads: Ill[ustrissi]mo Signore Presidente della Lezione [sic; should probably be 'Sezione'] Medica e Chirurgica del R[eggio]. Spedale di S[anta].M[aria]. Nuova. La sottoscritta, nata negli Stati Uniti di America, e domiciliata in Londra in Inghilterra proponendosi di passare l'inverno in Firenze prega V[ostra]. S[ignoria]. Ill[ustrissi]ma a volere accordare il favore di essere ammessa alla Lezione Ostetrica della Scuola Medica. Ho l'onore di inchiudere con questa delle testimoniali dello Spedale del Collegio della università di Londra. Con il respetto il piu grande, etc etc etc Sarah Parker Remond." (Cancelleria degli Studi Affari Spediti anno 1866-67, Filza 74, affare 11).

9. Letter dated "2 Via Mazzetta, Ottobre 30, 1866": "Illustrissimo Signore Presidente della Sezione Medico-Chirurgica della Scuola Medica del R[eggio]. Spedale di S[anta]. M[aria]. Nuova, Il sottoscritto, nativo di Boston / Stati Uniti / dimorante in Firenze rispettosamente espone: - Come essendo egli gia abilitato in Facoltà Medica e Chirurgica nei Collegi Medici della sua città nativa, come può facilmente rilevarsi dai qui uniti diplomi: e desiderando di poter prendere parte alle lezioni che si danno in questo Real Collegio presiduto da V[ostra]. S[ignoria]. ed è per ciò che fa domanda onde poter essere ammesso alle lezioni che vengono regolarmente date in questo Real Collegio Medico. Che è quanto etc, etc, B.B. Appleton, M.D. Mass[achusetts]. Med[ical]. Soc[iety]. Socius." The letter is accompanied by Appleton's business card. (Cancelleria degli Studi Affari Spediti anno 1866-67, Filza 74, affare 11).

10. I wish to thank David R. Daley at the Longfellow House - Washington's Headquarters NHS for this information.

11. The Revolution, 5 August 1869, page 73; The Christian Recorder, 7 August 1869, n.p.; The Revolution, 7 October 1869, page 218.

12. "Traduzione di No. 1," letter dated "Londra, Via Margherita, No. 82"; London 82 Margaret Street is about 15-minute walk from the UCL Medical School. "Io sento gran piacere nel dichiarare che la Signorina Remond ha ricevuto la sua educazione ed istruzione da guarda-malati in Medicina e Chirurgia allo Spedale del Collegio della Università. Ed io posso / nell'assenza della Madre Superiore / fortemente testificare del suo zelo nel travaglio: della sua abilità ed energia e della sua infaticabile attenzione e bontà verso i malati affidati e sottoposti alla sua assistenza. Firmato Sorella Rosmonda, di Tutti Santi, del Collegio dell'Università. 19 giugno 1866." (Cancelleria degli Studi Affari Spediti anno 1866-67, Filza 74, affare 11).

13. "Traduzione di No. 2"; letter dated "Londra, Via Weymouth, Piazza di Portland, 12 giugno, 1866." The date is 12 June 1866 and the address, London, Weymouth Street in Portland Square, close to the University College Hospital. "Cara Signorina Remond. Con molto piacere io cedo alla vostra domanda nello scrivere qualche cosa di quello che conosco in riguardo alla vostra esperienza nella cura e servizio-di-Spedale. Io, come uno dei Capo-Chirurghi del Collegio della Università, ho avuto l'opportunità di osservare il modo con quale ella ha fatto i suoi doveri nei diversi dipartimenti del Spedale, sotto la soprintendenza delle Sorelle; e mi era molto piacevole il vedere con quanta assiduità ella ha sempre reso i suoi servigii nei varii bisogni dei malati. Sono io pratico di molti Spedali, ed ho studiato in questi Stabilimenti in Inghilterra, e nel Continente. Perciò mi credo sicuro e capace di asserire che il Sistema praticato dalle Sorelle (di Ognissanti) nello Spedale del Collegio della Università è in tutti i riguardi eguale a quello adottato altrove: e che ella ha avuto le opportunità buoni d'imparare tutti i doveri necessari per riescire perfetta 
Guarda-Malata Ospedaliera. In mio giudizio ella è perciò capacissima di assumere l'incarico del servizio di uno Spedale, o di un dipartimento di uno Spedale. Augurando a lei ogni buona fortuna etc, etc, etc, Sono, cara Signorina Remond, Suo sincero amico. Firmato M. Berkeley Hill, ChirurgoAjutante del Collegio della Università" (Cancelleria degli Studi Affari Spediti anno 1866-67, Filza 74 , affare 11).

14. "Ill[ustrissi]mo Signore Cav. Comm President della Lezione [should probably be 'Sezione'] di Medicini [Medicina], etc.,

Sara Parker Remond di Boston, Stati Uniti di America, serva umilissima della S. V. Illma riverendamente espone che desiderando d'intraprendere la carriera di Ostetrica prega la S.V. Illma a volerla ammetere agli studii relative che si danno in contesta [sic] scuola.

La sopradetta S. P. Remond ha gia passato un anno nella Scuola.

No 8 Via S[anto] Spirito

13 November, 67. (Cancelleria degli Studi Affari Spediti anno 1867-68, Filza 79, affare 115).

15. Cancelleria degli Studi Affari Spediti anno 1867-68, Filza 77, affare 115.

16. Cancelleria degli Studi Affari Spediti anno 1867-68, Filza 77.

17. Cancelleria degli Studi Affari Spediti anno 1867-68, Filza 77.

18. "Sara Parker Rémond domanda di venire a studio nella clinica ostetrica" (Cancelleria degli Studi Affari Spediti anno 1867-68, Filza 77). The accent on the letter 'é' of her last name would indicate that the emphasis should be placed on the first syllable of the name. In the United States, her last name is commonly pronounced as if it were French, Rémond, which may have its origins in an American pronunciation of her father's original last name, probably of Dutch origins, which was recorded upon his arrival from the West Indies as "Vonreman," from what may have been "Van Reman."

19. “Copia. Sezione Medico Chirurgica et. Firenze li 22 Luglio 1868, No. 115, Oggetto Remond Sara Esami d'Abilitazione

Sara Remond d'America nel cod[esto]. anno chiese ed ottenne d'assistere come uditrice alle Lezioni d'ostetricia gle alunne. A Novembre p.p. sostenne l'esame d'ammissione ed entrò a far parte delle alunne [?].

Ora che ha seguito con rara diligenza le lezioni e soddisfatto a tutti gli obblighi scolastici chiederebbe gli Esami finali d'abilitazione.

In considerazione dell'esemplare condotta tenuta, del tempo fatto come uditrice e della pratica acquistata, proporrebbe il sottoscritto che [?] grazia speciale e da non allegarsi in esempio, le venisse accordato questa domanda.

Il Presidente, firmato Del Punta"

"copia. Ill[ustrissi]mo Presidente della Sezione degli Studi in S. M. Nuova.

Remond Sara d'America (Stati Uniti) [?] serva di V[ostra]. S[ignoria]. Illustrissima fa rispettosa istanza a cio voglia degnarsi ammetterla all'Esame di Matricola in Ostetricia nel con. mese di Luglio, avendo già terminato le pratiche e gli studi prescritti dai veglianti regolamenti.

Che è quanto, Firenze 2 Luglio 1868." (Soprintendenza del regio Ist. di studi Superiore anno 1868Filza 13)

20. Image 15: Ammissione all'Esame di Mat[ricola] Ostetrica delle alunne: Remond Parker Sara. “Copia. Remond Sara. Illustrissimo Presidente. La domanda delle alunne ostetriche a $2^{\circ}$ anno di cui è parola nelle di Lei officiale del $4 \mathrm{di}$ q[uest]o mese è diretta ad ottenere di poter prendere gli Esami di libera pratica prima del futuro Novembre. Il Ministero crede accordare questo favore nell'anno decorso; ed io non farei alieno dal proporre simile temporamento anche di quest'anno, se non avessi rimarcata molta negligenza nel maggior numero delle alunne. L'unica esemplarissima è l'americana Parker la quale però non avrebbe fatto che 8 mesi di studi legali invece di 16.

Io non vorrei parere troppo severo mettendo la domanda agli ordini, e non lo potrei nemmeno quando vedo i modi diversi ed il tempo di vario che si esige nelle varie Scuole d'Italia, che in 
alunne è anche della metà di quello che si vuole qui. Perciò rimetto interamente all Sua saviezza le relative proposizioni, essendo evidente che bisognerà tornare di proposito sull'ordinamento di questi Studi in tutto il Regno, dovendo essere eguali per tutti tanto i pregi quanto i vantaggi.

Ho l'onore di soscrivermi pieno di rispetto

di V.S. Illmo

li 19 Luglio 1868

Devoto Servitore

Prof Vincenzo Balocchi

Ref. Presidente della Sez[ione] Med[i]co Chiru[rgi]co

"Oggetto. Remond Sara: Esami d'abilitazione in ostetricia

Il Ministro sottoscritto, tenuto conto delle circostanze dichiarate nella nota contrassegnata acconsente che Sara Remond d'America venga ammessa, in via eccezionale e tenga che questo fatto possa addursi in esempio agli esami finali di abilitazione in ostetricia.

V. S. provederà a che la detta Remond sia di ciò informata, per opportuna sua norma, col mezzo del Presidente della Sezione di Medicina e Chirurgia al quale verrà pure restituire tal qui unita istanza.

Il Ministro

Napoli

Al Sig Sopraintendente del R[eggio] Istituto di Studi Superiori, Firenze"

Oggetto. Remond Sara, Esame d'abilitazione in ostetricia.

Il Minstero con resoluzione di ieri, tenuto conto delle circostanze dichiarato nella Nota controsegnato acconsento che Sara Remond d'America venga ammessa, in via eccezionale e tenga che questo fatto possa addursi in esempio, agli esami finali d'abilitazione di ostetricia.

Nel ritornare a codesta la Presidenza l'unità istanza, il sottoscritto tenga la I. V. a voler informare la richiedente di questa superiore concezione.

Al Presidente della Sezione di Medicina e Chirurgia. (Soprintendenza del regio Ist. di studi Superiore anno 1868-Filza 13)

Image 16: Firenze li 29 Luglio 1868

Il Minstero con resoluzione di ieri, tenuto conto delle circostanze dichiarato nella Nota controsegnato, acconsento che Sara Remond d'America venga ammessa, in via eccezionale, e tenga che questo fatto possa addursi in esempio, agli esami finali in ostetricia.

Nel ritornare a cod[est]a Presidenza l'unità istanza, il sottoscritto prega la S. V. Illsm a voler informare la richiedente di questa superiore concezione.

Remond Sara

Esame d'abilitazione in Ostetricia

Il Sopraintendente

Lambruschini

Al Presidente della Sezione Medico Chirurgico del 1 Istituto Sup[erior]e Firenze (Soprintendenza del regio Ist. di studi Superiore anno 1868-Filza 13)

Image 17: Ill[ustrissi]mo Sig[nor] Presidente della Sezione degli Studi in S[anta]. M[aria]. Nuova

Remond Sara di America (Stati Uniti) umilissima serva di V.S. Ill[ustrissi]ma fa rispettosa istanza accià voglia degnarsi ammetterla all'Esame di matricola in Ostetricia nel corrente mese di Luglio, avendo gia terminato le pratiche e gli Studi prescritti dai veglianti regolamenti.

Che è quanto

Firenze li 2 Luglio 1868 (Soprintendenza del regio Ist. di studi Superiore anno 1868-Filza 13)

21. 1867-68 Scuola Ostetrica

Remond Sarah Parker figlia di John - nativa di Salem Stati Uniti 
Martedi 4 agosto 1868

Esame di riprova pratica F. 3. C. 0

11 agosto 1868

Esame di abilitazione F. 3 C. 0 (Cancelleria degli Studi Affari Spediti anno 1867-68, Filza 79)

22. For more about ethical questions, see, for example McKee and Porter.

\section{ABSTRACTS}

Through the case study of Sarah Parker Remond (1826-1894), this essay reflects on the significance of archival research in recovering historical narratives that have been erased. Recently, universities have recognized the benefits of student involvement in archival work and started to use it as a pedagogical tool that has resulted in increased student engagement in knowledge production and in the recovery of neglected histories. Sharing stories recovered from various archives, such as that of the African American abolitionist, women's rights advocate, and doctor Sarah Remond, generates awareness of the ways in which experiences and the contribution of the marginalized, many of them women, may remain overshadowed by mainstream narratives. The essay includes archival documents, rendering them, now for the first time, accessible to others, and contributes to the rewriting of the stories of such inspirational women as Remond back into the history that erased them.

À travers l'exemple de Sarah Parker Remond (1826-1894), cet essai réfléchit à l'importance de la recherche archivistique dans la récupération de récits historiques qui ont été effacés. Récemment, les universités ont reconnu les avantages de la participation des étudiant·es au travail d'archives et ont commencé à l'utiliser comme un outil pédagogique, ce qui a entraîné un engagement accru des étudiant·e's dans la production de savoirs et la sauvegarde d'histoires négligées. Ces histoires, telle celle de la militante afro-américaine, promotrice des droits des femmes et médecin Sarah Remond, nous fait prendre conscience de la manière dont les expériences, et la contribution des personnes marginalisées, parmi lesquelles beaucoup sont des femmes, peuvent continuer à être effacées par des récits dominants. L'essai entend rendre accessibles pour la première fois des documents d'archives à grande échelle, et espère contribuer à la réécriture des histoires de femmes exceptionnelles telles que Remond.

\section{INDEX}

Mots-clés: Remond (Sarah Parker), recherche archivistique, sauvegarde historique, réécrire l'histoire, outils pédagogiques

Keywords: Remond (Sarah Parker), archival research, recovery work, rewriting history, pedagogical tools

\section{AUTHOR}

\section{SIRPA SALENIUS}

University of Eastern Finland 